\title{
Determinant of Regional Economic Growth in East Java, Indonesia
}

\author{
Muchlas M. Sengaji ${ }^{1}$, Sasongko ${ }^{1}$, Rachmad K. Sakti ${ }^{1}$ \\ ${ }^{1}$ Faculty of Economics and Business, Brawijaya University \\ E-mail: irulsengaji@gmail.com
}

Received: November, 2018; Accepted: September, 2019; Published: November, 2019 Permalink/DOI: http://dx.doi.org/10.17977/um002v11i22019p104

\begin{abstract}
National economic growth is an aggregation of regional economic growth. Growth is also the main measure of development success. The existence of fiscal decentralization provides flexibility to local governments in regulating their regions and making policies that can support the potentials in their regions. This study aims to analyze and provide empirical evidence about the determinants of economic growth in 38 regencies/cities in East Java Province in 2010 to 2016 including Locally-generated Revenues (PAD), General Allocation Funds (DAU), Special Allocation Funds (DAK), Revenue Sharing Funds (DBH), Indirect Expenditures, Direct Expenditure, and Remaining Over Budget Financing (SiLPA). From the results of the Fixed Effect model, it was found that the PAD, DAU, DBH and Direct Expenditure had a positive significant effect on economic growth, while the DAK and Indirect Spending variable had no significant effect on economic growth. SiLPA also had no significant effect on economic growth. The last, simultaneously, PAD, DAU, DAK, DBH, Direct Expenditure, Indirect Expenditure and SiLPA had a significant effect on economic growth.
\end{abstract}

Keywords: Locally-generated Revenue, General Allocation Funds, Special Allocation Funds

JEL Classification: C3, E62, H5, 04

\section{INTRODUCTION}

Economic growth is a necessary condition in carrying out economic development. Growth is also the main measure of development success. Shortly, economic growth is a process of increasing output per capita in the long run (Boediono, 1992). This understanding emphasizes three things, namely process, output per capita and long term. The process of describing economic development over time is more dynamic. Per capita output links aspects of total output (GDP) and aspects of population, while the long term will show a pattern of trends in economic changes in a certain period of time driven by internal economic processes (self generating). The progress of sustainable economic growth in each region is a concern of the government because basically national economic growth is an aggregation of regional economic growth.

Economic growth between regions in Indonesia is very diverse. This diversity is one of the factors that gives rise to the concept of developed and less developed regions. The growth towards a more equitable and balanced paradigm of development realized through the regional autonomy policy that began to be 
implemented effectively on January 1, 2001 had a broad and serious implication for the Indonesian nation, where the application of regional autonomy was seen as democratic and fulfilling the real aspects of government decentralization.

The legitimation of Law No. 22 of 1999 concerning Regional Government and Law No. 25 of 1999 concerning Financial Balance between Central and Regional Governments, which was later amended to become Law No. 32 of 2004 and Law No. 33 of 2004, then there have been fundamental changes to the regional financial system. This means that the central government has given full authority to the government to manage and manage their own households with little interference from the central government. This policy is a challenge and opportunity for local governments because local governments have greater authority to manage their resources efficiently and effectively.

Regional autonomy is expected to be a stimulus for local governments to encourage economic efficiency and efficiency of public services so that they can encourage regional economic growth and improve the welfare of local residents through multiplier effects of decentralization that are expected to be realized (Khusaini, 2006). One of the provinces in Indonesia which has a fairly good regional financial performance in the fiscal decentralization era is East Java Province. But East Java as one of the provinces in Indonesia is also inseparable from the problem of inequality in economic development. The aspect of income distribution is an important thing to observe, because equitable development outcomes are one of the strategies and goals of national development in Indonesia. So that in practice how the development process that occurs in the area can be maximized and at the same time minimize the value of development inequality. The trick is to maximize economic sectors that have the value of competitive advantage in each region. Moreover, East Java is a very potential province with considerable economic development potential.

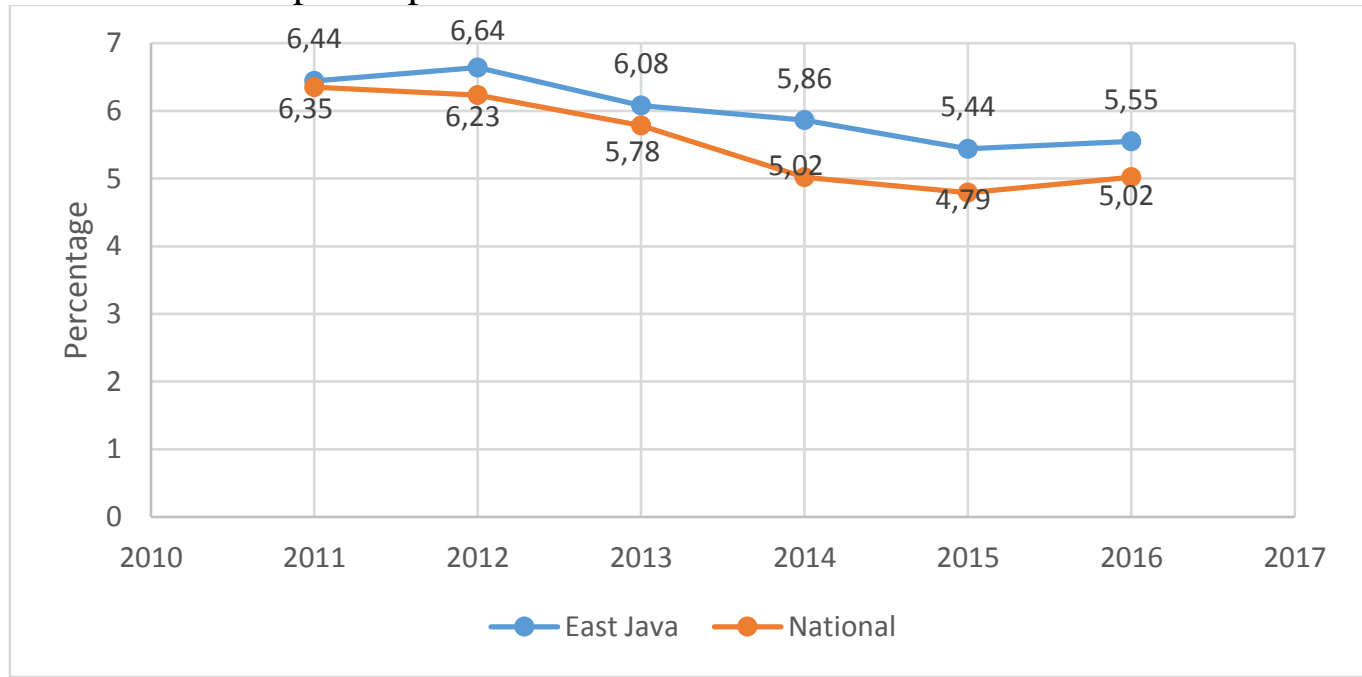

Figure 1. National and East Java Economic Growth.

Source: Data processed

From the figure one we can see that the rate of economic growth (cumulative economic growth) in East Java up to the fourth quarter of 2016 reached 5.55 percent and was the highest economic growth in Java and 0.53 points higher than national 
economic growth (5,02 percent). That way, East Java is able to contribute to 34 provinces (national) of 14.44 percent.

Economic equality in East Java Province between regencies / cities is still a matter of concern between the provincial and district / city governments. The economic contribution of the central district / city continues to dominate and even its contribution has increased. Economic growth in the regency / city of East Java province every year experiences positive economic growth but when seen between districts / cities in the province of East Java there are still differences in uneven economic growth, where economic growth in each region still shows a significant difference.

We can see from the value of GRDP between regions in regencies / cities in East Java, it still shows that there are gaps that are quite far in each region. Up to the second semester of 2016 the highest GDP was shown by the city of Surabaya at 343,652.6 (in billion rupiahs), while the lowest was in the city of Blitar, amounting to 4079.3 (in billion rupiahs). This shows that there is still an uneven distribution of income between regencies / cities in East Java Province. The difference in resources and infrastructure indeed greatly affects the East Java region but seen from the GRDP inequality from the highest to the lowest is very much different and this shows that the distribution of income between regencies / cities in East Java Province is still uneven.

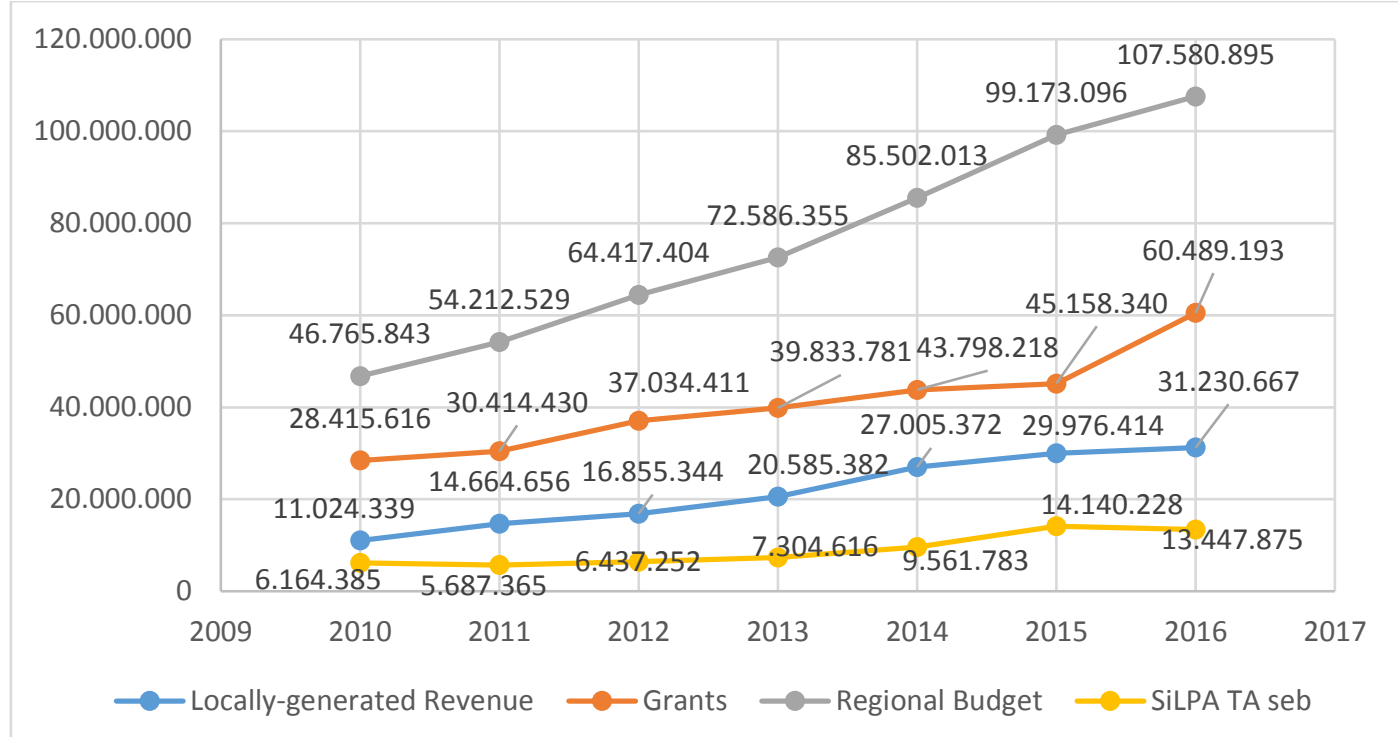

Figure 2. Composition of PAD, Grants, Regional Expenditures and Silpa in 38 East Java Province / Cities (In Million Rupiah).

Source: Data processed

From the figure two, we can see that in each year there has been an increase in both Local Revenue, Grants and SiLPA. Kuncoro (2004); Adi (2008) and Afizawati (2012) said that, in practice, the transfer from the central government was the main source of funding for the local government to finance its main daily operations. Figure two proves that the largest portion in spending regional needs is most supported by grants than Locally-generated revenue (PAD). This causes local governments always demanding greater grants to the central government. This shows a mismatch between the reality that occurs in Region / City of East Java Province with the aim of regional autonomy, to make the region independent of its 
potential. According to Oates and Gamkhar (1999), to maintain the amount of funds obtained from the central government, local governments will increase the amount of significant regional expenditure. This causes the use of PAD in spending needs become not optimal and resulting asymmetrical phenomena.

Based on the background and explanation above, this study aims to determine the economic growth determinants of the Regency / City of East Java Province. In this study several variables were developed, namely Regional Original Revenue, General Allocation Funds, Special Allocation Funds, Revenue Sharing Funds, Direct Shopping, Shopping Not directly and Remaining More Budget Financing. The relationship between these variables is explained in the grand theory used in the research, namely the Keynessian Growth Theory is a source of legitimacy for the Keynesian view of the relevance of government interference in the interregional economy.

The problem of economic growth as shown in the phenomenon that happened in Regency / City of East Java Province, if not followed up quickly will cause macroeconomic problems in the long term and will affect the financial performance of the region both districts and cities because economic growth is the key to macroeconomic goals . Fiscal decentralization on the one hand provides greater authority in regional management, but on the other hand provides new problems, due to different levels of regional fiscal readiness.

\section{METHOD}

\section{Type and Source of Data}

In this study using a quantitative approach with quantitative descriptive analysis method. This research was conducted with the scope of the area of 38 City Regencies of East Java Province with a research period from 2010-2016. The data used in this study are secondary data obtained from the Ministry of Finance, DJPK, DJP, Central Bureau of Statistics (BPS) and the Regional Development Planning Agency (BAPPEDA) and other relevant agencies. The data in the study are Realization of Original Revenue, General Allocation Funds, Special Allocation Funds, Revenue Sharing, Non-slim Expenditures, Direct and SiLPA Expenditures for each Regency of East Java Province.

This study uses economic growth as the dependent variable. According to Bappenas, economic growth can be calculated using gross regional domestic products in the current and previous years, while the independent variable in this study is Locally-generated Revenue (PAD) with The formula for PAD is the Regional Tax + Regional Retribution + HPKDD + other legal PAD (Law No. 33 of 2004), General Allocation Funds (DAU) with the Fiscal Gap + Basic Allocation equation. Gap Fiscal is Financial Needs - Fiscal Capacity, Special Allocation Funds (DAK), Revenue Sharing Funds (DBH) (Law No. 33 of 2004), Indirect Expenditure, Direct Expenditure, and Remaining Over Budget Financing (SiLPA) (Permendagri Number 13 of 2006).

\section{Data Analysis Method}

This study uses several methods of analysis in answering the objectives to be achieved. The analysis tools include determination of the estimation method is Chow test (This test is used to determine the selection of the Pool Least Square or Fixxed Eeffet method), Hausman test (This test is used to determine the selection 
between Fixed or Random Effect methods) and Lagrange Multiplier test (This test is used to determine the choice between the Common Effect or Random Effect method.). The result show that the analysis data used the fixed effect model and statistical testing is done, namely Partial Test ( $\mathrm{t}$ Test) basically show how far the influence of one independent variable or independent variable individually explains the variations of the dependent variable, Simultaneous Test (F test) basically show whether all the independent variables included in the model have simultaneous influence and coefficient of Determination $\left(\mathrm{R}^{2}\right)$ measures the level of accuracy or compatibility of panel data regression, which is the proportion of the percentage of contributions of independent variables $(\mathrm{X} 1, \mathrm{X} 2, \mathrm{Xn})$ to the variation (rise and fall) of the dependent variable (Y).

The equations used in this study were formulated as follow :

$$
\begin{gathered}
\log (\text { Yit }): \alpha+\beta 1 \log (\mathrm{PADit})+\beta 2 \log (\mathrm{SiLPait})+\beta 3 \log (\mathrm{DAUit})+\beta 4 \log (\mathrm{DAK} i t)+ \\
\beta 5 \log (\mathrm{DBH} i t)+\beta 6 \log (\mathrm{BTLit})+\beta 7 \log (\mathrm{BLit}) \text { eit },
\end{gathered}
$$

$\begin{array}{lll}\log (\text { Yit }) & : & \text { Economic Growth, } \\ \alpha & : & \text { Constant, } \\ \beta 1 \beta 2 \beta 31 & : & \text { Regression Coefficient, } \\ \log (\text { PADit }) & : & \text { District Original Revenue i in year t, } \\ \log (\text { SiLPait }) & : & \text { Over Time Budget Financing, } \\ \log (\text { DAUit }) & : & \text { Fund Transfer General Allocation, } \\ \log (\text { DAKit }) & : & \text { Special Allocation Fund, } \\ \log (\text { DBHit }) & : & \text { Revenue Sharing Fund (DBH), } \\ \log (\text { BTLit }) & : & \text { Indirect Expenditures, } \\ \log (\text { BLit }) & : & \text { Direct Spending, } \\ \text { eit } & : & \text { Term Error }\end{array}$

\section{RESULTS AND DISCUSSION (Capital, 12 pts, bold) Data Analysis}

One step in determining the best model in panel data research is to do the Chow Test. The hypothesis in the chow test is to use Likehood Ratio. The Chow test is used to test the best model between the common effect and the fixed effect model. Based on the results of processed eviews 9.0 can be seen that the Chisquared probability or the $\mathrm{p}$-value $\mathrm{Obs} * \mathrm{r}$ square is 0.00 or smaller than the critical point of 0.05 or p-value $\mathrm{Obs} * \mathrm{r}$ square $0,000<0,05$ then $\mathrm{H} 0$ is rejected. Then it can be concluded that at the $95 \%$ confidence level the model that is better used for this study is the Fixed Effect Model. The Hausman test can be defined as a statistical test to choose whether the most effective Fixed Effect or Random Effect model is used. Based on the results of outpus eviws 9.0 can be seen that the Chi-squared probability value or the Ob-value $\mathrm{p}$-value $* \mathrm{r}$ square is 0.00 or smaller than the critical point of 0.05 or the $\mathrm{p}$-value $\mathrm{Obs} * \mathrm{r}$ square $<0,05$ then $\mathrm{H} 0$ is rejected. Then it can be concluded that the model that is suitable is the Fixed Effect Model.

\section{Results of Panel Data Regression}

Research with data processing is done with Eviews 9.00 software and serves to test the panel data model, which includes, testing statistical criteria, and testing hypotheses. The following are the results of the regression processed by Eviews 
9.00. From the table 4 related to regression estimation of panel data using the fixed effect model above, the regression equation can be arranged as follows:

$\log$ PEit : 2,520317 + 0,158311 log (PAD) + (-0.001218) $\log ($ SiLPA $)+$ $0.028969 \log (\mathrm{DAU})+(-0,014638) \log (\mathrm{DAK})+0.25375 \log (\mathrm{DBH})+0.017430$

$$
\log (\mathrm{BTL})+0.033962 \log (\mathrm{BL})+\text { eit }
$$

Table 4. Data Panel Regression Estimation With Fixed Effect Model

\begin{tabular}{|c|c|c|c|c|}
\hline Dependent Variabel & \multicolumn{4}{|c|}{ : Log PE (Economic Growth) } \\
\hline Method & \multicolumn{4}{|c|}{ : Panel Least Squares using Fixxed Effect Model } \\
\hline Period & \\
\hline Cross-Section & \multirow{2}{*}{\multicolumn{4}{|c|}{$\begin{array}{l}\text { : } 38 \text { (29 Districts and } 9 \text { Cities East Java Provincies } \\
\text { : } 266 \text { Observations }(7 \times 38)\end{array}$}} \\
\hline Observation & & & & \\
\hline Var $(\log )$ & Coefisien & Std Error & T-statistik & Prob. \\
\hline $\log B L$ & 0.03396 & 0.01157 & 2.93427 & 0.0037 \\
\hline $\operatorname{logBTL}$ & 0.01743 & 0.02680 & 0.65023 & 0.5162 \\
\hline $\log \mathrm{DAK}$ & 0.01463 & 0.00449 & 3.25346 & 0.2130 \\
\hline $\log \mathrm{DAU}$ & 0.02896 & 0.01178 & 2.45721 & 0.0148 \\
\hline $\log \mathrm{DBH}$ & 0.02537 & 0.01225 & 2.07073 & 0.0395 \\
\hline $\log \mathrm{PAD}$ & 0.15831 & 0.01363 & 11.6080 & 0.0000 \\
\hline $\operatorname{logSiLPA}$ & -0.00121 & 0.00746 & -0.16320 & 0.8705 \\
\hline $\mathrm{C}$ & 2.52031 & 0.49408 & 5.10094 & 0.0000 \\
\hline R-squared & & 0.7998 & Mean depent var & 9.8084 \\
\hline Adjusted R-squared & & 0.7941 & S.D. depent var & 0.9671 \\
\hline F-statistic & & 4331.4 & Hannan-Q. crit & -3.4116 \\
\hline Prob(F-statistic) & & 0.0000 & Durbin-W. stat & 1.1143 \\
\hline
\end{tabular}

From the results of regresi output shows that the variable X1 (Direct Spending), variable X4 (General Allocation Fund), variable X5 (Revenue Sharing) and variable X6 (Regional Original Revenue) shows a significant level below the critical value of $5 \%$ so it can be concluded that Direct Spending, General Allocation Funds, Revenue Sharing Funds and Regional Original Revenues partially affect Economic Growth while variable X2 (Indirect Expenditures), X3 variables (Special Allocation Funds) and SiLPA variables (Remaining Over Budget Financing) show a significance level below alpha $5 \%$ so that it can be concluded that the Indirect Spending, Special Allocation Funds and SiLPA partially have no effect on Economic Growth.

Based on the table above, it can be concluded that simultaneous hypothesis testing of the independent variables on the dependent variable. In the table above shows that the probability value (f-statistic) is 0,000 or in other words $0,000<0,05$ ) means that together or simultaneously have a significant effect on Economic Growth. From the table above shows the results of sil test using Fixed Effect Model which produces an adjusted R2 value of 0799842 (79.9\%). This shows that the ability to explain the independent variables (Direct Expenditures, Indirect Expenditures, General Allocation Funds, Special Allocation Funds, Profit Sharing Funds, Regional Original Income and Remaining More Budget Financing) to the dependent variable is $79.9 \%$, while the remainder is $20.1 \%$ is explained by other variables outside of the seven independent variables which are not included in the model. 


\section{Discussion}

In accordance with the results with the Fixed Effect Model (FEM) method that has been chosen as the method used in the study and has been explained previously, then in this discussion an explanation of the results of the findings of Local Revenue, Direct Expenditures, Indirect Expenditures, General Allocation Funds will be presented. Special Allocation Funds, Profit Sharing Funds and SiLPA for Economic Growth in Districts / Cities in East Java Province 2010-2016.

The results of the research analysis explain that Regional Original Income (PAD) has a significant and positive influence on Regional Economic Growth produced by the District / City Government in the East Java Province. This means that the higher or greater the PAD generated by the Regency / City in East Java Province will have a direct or positive influence on Regional Economic Growth. The results of this study are in line with the research conducted by Mawarni (2013); Zuwesty Eka (2015) dan Gunantara (2014) who obtained a direct test that PAD showed a positive influence on Economic Growth. Sidik (2000) dan Apriana (2010) explained that the success of increasing PAD should not only be measured by the amount received, but also measured by its role in regulating the regional economy, so that the regional government will take the initiative to explore the potential of the region.

One of them is by providing a larger proportion of capital expenditure for development. With the development of infrastructure / development and infrastructure by the regional government, it will have an impact on regional economic growth. With the increase in economic activity in the community, there will be an increase in the number of outputs of goods and or services followed by an increase in the money supply in terms of expenditures made by regional governments. Furthermore, this will increase the value of Regional Domestic Products and the level of community welfare. Similar conclusions are expressed by Gunantara and Dwirandra (2014). Saragih (2003) explained that the increase in PAD must have an impact on the regional economy. Therefore, regions will not succeed if the regions do not experience significant economic growth despite increased revenues. If the opposite happens, it can be indicated that there is excessive exploitation of PAD towards the community without regard to increasing the productivity of the community itself.

The results of the study explained that the General Allocation Fund (DAU) had a significant positive effect on Economic Growth produced by the local government of the City of East Java. The results of this study are in line or in accordance with the research conducted by Gunantara and dwirandra (2014); Aulia Afafun (2017) which explain that the role of DAU has a positive influence on regional economic growth. The increase in DAU from year to year aims to close the fiscal gap and as an equalization grant that neutralizes financial inequality and evenly distributes fiscal capacity between districts / cities in East Java so that the allocation of DAU per region will not be the same. The fact shows that in each regency / city in East Java Province every year the composition of the DAU in financing operations or daily needs is always greater than other revenues.

This is in accordance with the statement Maimunah (2008) who said that the practice of transfers from the central government was the main source of funding for local governments to finance their daily main operations. Maimunah's statement was also reinforced by statements from Adi (2008); Afrizawati (2012). 
This illustrates that with the increase in DAU (general allocation funds) by the Central Government, it will have a positive influence on Economic Growth by allocating DAU funds to be used in financing or regional needs, for example with capital expenditure or other expenditures so as to provide multiplayer effects on growth the economy of the Regency / City of East Java Province but on the one hand the increase in the DAU portion will cause the level of independence of a region to be reduced because it will cause an effect of dependence on the Central Government. The effect of this dependence may be due to the low management of DAU funds.

The results of the study explained that the Special Allocation Fund (DAK) variable showed no significant effect on Economic Growth produced by the district / city government in East Java Province. When compared with previous research conducted by Ardiansyah et al. (2015) and Muhammad Hasan (2015 who said that DAK had a partially significant effect on Economic Growth, this study was not consistent with previous research, whereas research conducted by Jolianis (2016) and Anis Setiawati (2007) found that DAK had no significant positive effect in accordance with the results of the study. This is because the value of DAK received by regional governments is used to fund special activities which are regional affairs.

Specific activities referred to are in accordance with the functions set out by the APBN for example for public services, education and others, which means that they should not be misused or used for activities outside the provisions. So what happens here is that there is stiffness in managing DAK funds that must be adjusted to what has been determined by the Central Government. Unlike the DAU, the use of DAK by the regions is not flexible and free but must follow various regulations from the central government. As we know that the allocation of DAK is more focused on development investment activities, procurement, improvement, and repair of physical facilities and infrastructure with a long economic life, including the provision of useful physical support facilities. for the public This gives an understanding that the policies used in the implementation are still focused on input-oriented so that it will cause some areas of difficulties or use DAK funds according to the targets and needs set.

The results of the study show that the Revenue Sharing Fund (DBH) has a positive and significant effect on the Regency / City Economic Growth of East Java Province. The results of previous studies conducted by Lukman Hakim et al. and Muhammad Hasan (2015) state that the role of DBH allocations has a significant effect on the level of economic growth so that this study is consistent with previous research. The allocation of DBH funds is different from the Special Fund, which in its use is more flexible, the allocation can be combined also with local revenue and other Revenues, where the use of the allocation will be in accordance with regional expenditure needs and improvement of public services in the region. DBH allocation as a source of infrastructure financing in the form of economic facilities and infrastructure will support the production of goods and services by investors from the local community or from outside the area concerned. With the emergence of investment activities will further create employment opportunities, and create multiple effects so as to provide a positive influence on economic growth in the Regency / City of East Java Province.

The results of the research show that direct spending has a positive and significant influence on Regency / City Economic Growth in East Java. The results 
of this study are in line or consistent with the research conducted by Osborn (2007), Barro and Salla Martin (1995), Armin (2005), Deviani (2016) and Andri Novandy (2015) which show that direct expenditure variables have a positive and significant effect on economic growth. This can be seen from the most significant regional expenditure indicated by the portion of Goods and Services Expenditures with an average of $53.46 \%$, Capital Expenditure has an average of $45.33 \%$, and $1.19 \%$ for personnel expenditure. Capital expenditure and expenditures for goods and services are used by the government to increase regional economic growth by carrying out investment expenditures, starting from allocating capital expenditure allocations for goods and services expenditures in the form of fixed assets such as infrastructure development, construction of regional infrastructure which are considered very important for the regional economy. If public facilities and infrastructure have been fulfilled and are considered adequate to be used by the community, the implementation of day-to-day activities can be carried out safely and comfortably which will also affect the increasing level of community productivity. In addition, adequate infrastructure will also attract investors to open businesses in the area. So it can be concluded that the amount of the budget issued by the regional government is directly proportional to the effectiveness of local governments in building economic growth itself in the regencies / cities in East Java.

The results showed that the indirect spending variable had a positive but not significant effect on Economic Growth. The results of this study are consistent with the research conducted by Osborn, DR (2007) through research on public expenditure and economic growth: dissaggated analysis for developing countries (1970s and 1990s) in the UK which explains that capital expenditures have a significant effect on routine expenditures that have no significant effect on Economic growth. Another study conducted by Arini and Dwi Mustika (2015) explained that the general service function expenditure, other function service spending actually decreases economic growth. The main objective in indirect expenditure allocation is to improve public services in the regions. From the results of data analysis shows that the indirect expenditure is still used for ineffective needs, namely the portion that is currently large in employee expenditure. This gives the fact that indirect spending is not directed to basic services such as education, health and the availability of public services to improve community welfare or in other words ineffective in managing the budget so as to enable people to get better services that are not achieved so that they will have an effect or the impact on regional economic growth.

The results of statistical tests show that SiLPA has no significant effect towards economic growth in the Regency / City in the Province of East Java. This shows that the size of SiLPA in regency / city governments in East Java has no significant effect on the ups and downs of economic growth. The results of this study are in line with the research conducted by Andry Novandi (2015) which states that SiLPA in an institutional perspective has no significant effect on East Java's economic growth. The amount of SiLPA produced by a region cannot be used as a benchmark for performance of local governments. Thus, it can be said that the high and low SiLPA does not necessarily indicate the good performance of the local government concerned. The increase in SiLPA which is increasing year by year is also done deliberately by the local government, because the higher the SiLPA, the regional government is motivated to make productivity-based investments in 
Regional Development Banks, for example Bank Jatim, and capital participation so that the results can increase regional income in the year next budget.

The negative indication of SiLPA comes from the rest of budget usage which is not caused by the efficiency and effectiveness of budget use. This means that SiLPA formed is caused by inaccuracies in budgeting and weakness in budget execution so that planned programs and activities cannot be carried out optimally. SiLPA funds that are too large must be avoided, because basically SiLPA is an idle fund, if it is not used carefully, it will not provide a multiplier effect for the regional economy. Seeing the facts about SiLPA, the proper management of SiLPA needs to be carried out by the local government. A large SiLPA must be minimized, one of which is by optimizing the use of SiLPA the previous year to increase the absorption of capital expenditures so as to provide an effect on the region's economic growth.

\section{CONCLUSION (Capital, 12 pts, bold)}

There are several variables that has significant influence and positive impact on economic growth in the Regency / City of East Java Province, they are Locallygenerated Revenue (PAD), and central transfer funds that consist of General Allocation Funds, Revenue Sharing Funds and Direct Expenditures. While Remaining Over Budget Financing does not have a significant effect on economic growth in the Regency/ City of East Java Province during the study period. The increase of Locally-generated Revenue and Central Transfer Funds will stimulus to regional cash so it can be spent on development and infrastructure that will create multiplayer effects on economic activity and the impact will provide a boost to regional economic growth. Too large SiLPA funds will causing these funds to be idle, so if it cannot be utilized carefully it will give negative contribution to economic growth in the Regency / City of East Java Province. The Special Allocation Fund Variables and Indirect Expenditures have no significant effect on economic growth in the East Java Regency / City during the study period. This is not in line or contrary to the initial hypothesis which states that there is a relationship between variables. This is because the increase in the total allocation of Special Funds and Indirect Expenditures is not directed to the basic needs of the region and is not effective in managing the budget. Rigidity in using the budget is also one of the causes so that some regions have difficulties or utilize allocation and expenditure funds not according to the targets and needs set.

Some suggestions put forward relating to the results of this study are: (1) District / City Governments in East Java Province should continue to be able to boost the value of Regional Original Revenue as the main component of regional income revenues by exploring good potential and regional development by intensifying and extensification of regional taxes or levies (2) Related to central government assistance to regional governments where the central government must also oversee the allocation of General Allocation Funds and Profit Sharing Funds so that allocations are not misused so that even distribution of disparities between regions can also lead to increased economic growth of Regency/City. (3) DAK planning should go through the Musrenbangda and Musrenbangnas processes. (4) Efforts to allocate expenditure efficiently and productively are targets that must be done by the Regency / City Government of East Java Province in order to provide the output, outcome, and multiplier effects that are felt in the form of public services 
to the community and the implementation of spending and supervision standards in District / City budget plan for East Java Province. (5) Need to be careful and reliable in managing SiLPA budgets each year.

\section{REFERENCES}

Adi, P. H. (2008). Hubungan antara pertumbuhan ekonomi daerah, belanja pembangunan dan pendapatan asli daerah. Dalam Simposium Nasional Akuntansi IX Padang.

Afrizawati. (2012). Analisis Flypaper Effect Pada Belanja Daerah Kabupaten/Kota di Sumatera Selatan. Journal Ekonomi dan InformasiAkuntansi, 2(1), 2130 .

Apriana, D., Suryanto R. (2010). Analisis Hubungan antara Belanja Modal dan Pendapatan Asli Daerah, Kemandirian Daerah dan Pertumbuhan Ekonomi Daerah. Jurnal Akuntansi dan Investasi, 11(1), 68-79.

Mustika, M. D. S., \& Arini, A. (2015). Pengaruh Pendapatan Asli Daerah dan Belanja Tidak Langsung terhadap Kemiskinan melalui Pertumbuhan Ekonomi di Provinsi Bali Tahun 2007-2013. E-Jurnal Ekonomi Pembangunan Universitas Udayana, 4(9).

Bailey, White.(1995).Decentralization, Governance and Public Services The Impact OfInstitutional Arrangements, IRIS Center, University of Maryland.College Park.

Barro, Robert J., dan Xavier, Sala-i-Martin. (1991). Convergence Across States and Regions.Brooking Papers on Economic Activity. Journal of Economic. 16 (2), 407-433.

Boediono. (1992). Pengantar Ilmu Ekonomi No.4 : Teori Pertumbuhan Ekonomi Edisi Pertama,.Edisi Pertama,Yogyakarta: BPFE.

Bose, N., Haque, M. E., \& Osborn, D. R. (2007). Public expenditure and economic growth: A disaggregated analysis for developing countries. The Manchester School, 75(5), 533-556.

Deviani. 2016. Analisis Belanja Daerah terhadap Pertumbuhan Ekonomi dan Pendidikan (Studi Empiris Kota dan Kabupaten di Simatera Barat). Jurnal Bisnis, 8(1), 1-13.

Eka, Putri .Z. (2015). Analisis Pengaruh Pendapatan Asli Daerah, Dana Alokasi Umum dan Inflasi terhadap Pertumbuhan Ekonomi Kabupaten/Kota Jawa Tengah. Jurnal Bisnis dan Manajemen, 5(2), 173-186.

Gamkhar, S., \& Oates, W. (1996). Asymmetries in the response to increases and decreases in intergovernmental grants: Some empirical findings. National tax journal, 501-512.

Gunantara, P. C., \& Dwirandra, A. A. N. B. (2014). Pengaruh Pendapatan Asli Daerah dan Dana Alokasi Umum pada Pertumbuhan Ekonomi dengan Belanja Modal sebagai Variabel Pemoderasi di Bali. Jurnal Akuntansi Universitas Udayana, 7(3), 529-546.

Hasan, M. (2015). Pengaruh Dana Transfer Pusat terhadap Pertumbuhan Ekonomi Daerah Kabupaten/Kota di Sulawesi Selatan. Economix, 3(1).

Jolianis, K. (2016). Analisis Pengaruh PAD, DAU dan DAK terhadap Kemiskinan Kabupaten/Kota di Provinsi Sumatera Barat dengan Pertumbuhan Ekonomi sebagai variable Intervening. Journal of Economic and Economic Education, 4(2), 192-209. 
Khusaini, M. (2006). Ekonomi Publik Desentralisasi Fiscal dan Pembangunan Daerah. BPFE Universitas Brawijaya.

Kuncoro, H. (2004). Pengaruh Transfer Antar Pemerintah pada Kinerja Fiskal Pemerintah Daerah Kota dan Kabupaten di Indonesia. Jurnal Ekonomi Pembangunan, 9(1), 47-63.

Maimunah, M. (2006). Flypaper Effect pada Dana Alokasi Umum (DAU) dan Pendapatan Asli Daerah (PAD) terhadap Belanja Daerah pada Kabupaten/Kota di Pulau Sumatera (Doctoral dissertation, Universitas Gadjah Mada).

Mawarni, D., \& Syukriy, A. (2013). Pengaruh Pendapatan Asli Daerah dan Dana Alokasi Umum Terhadap Belanja Modal Serta Dampaknya Terhadap Pertumbuhan Ekonomi Daerah Studi Pada Kabupaten dan Kota Di Aceh. Jurnal Akuntansi, 2(2), 80-90.

Novandy, A. Pengaruh Belanja Langsung Dan Sisa Lebih Perhitungan Anggaran (Silpa) Terhadap Pertumbuhan Ekonomi (Survei Pada Pemerintah Daerah Kabupaten/kota Di Provinsi Sulawesi Tengah). Katalogis, 3(9).

Saragih, Juli Panglima. (2003). Desentralisasi Fiskal dan Keuangan Daerah dalam Otonomi. Penerbit Ghalia Indonesia.

Sidik, M., Hidayanto, D., Ismail, T., Kadajdjatmiko., Pakpahan, AT., \& Adriansyah. (2004). Potensi Fiskal Terhadap Pertumbuhan Ekonomi dan Kesejahteraan Masyarakat. Jurnal Ekonomi Pembangunan, 12(2), 281-296. 